Received: 25.01.2021.

doi: 10.46763/JESPT211610071d

udc: 821.163.3-93-344.09

Revised: 18.02.2021.

Accepted: 15.03.2021.

\title{
A NEW TYPE OF ANTI-FAIRY TALE AGAINST PREJUDICE
}

\author{
Jovanka Denkova' \\ 'Faculty of Philology, Goce Delcev University, Stip, Macedonia \\ jovanka.denkova@ugd.edu.mk
}

\begin{abstract}
In this article we refer to a newer work of contemporary Macedonian literature for children. It is about the novel "Zvezda Mrak and the Creatures from Straskograd" from the contemporary Macedonian writer for children, member of the latest generation of authors for children and youth - Biljana S. Crvenkovska. The original concept on which this work is based, intrigues us to pay more attention to it, because without a doubt, the work deserves it. Namely, the work is based on the story and its basic elements, but the author only takes the conception and structure of the story to speak about today, about some universal problems of humanity, such as stigmatization, discrimination, rejection of all those, and everything which is different from the usual.
\end{abstract}

Keywords: literature for children, novel for children and youth, Biljana S. Crvenkovska.

\section{Introduction}

Biljana Crvenkovska was born in 1973. She graduated in 1996 at the Faculty of Philosophy (Philosophy Group). He is currently preparing a master's thesis at the same faculty. Published works: "Philosophy of the inexpressible" in: Samuel Beckett, "Selected plays", Detska Radost, Skopje, 1998; "The Myth-Tragic Code in the Macedonian Bloody Wedding" in: Macedonian Bloody Wedding - One Hundred Years Later, Jelena Luzina, MaticaMakedonska and Faculty of Drama Arts, Skopje, 2000. Biljana Crvenkovska is a writer, screenwriter, translator and editor. We recognize her by the stories from "Bibi's World", "Zvezda Mrak and the creatures from Straskograd", the children's novels "The Witch, the cat and the six magic cookies" and "What Santa dreamed", the illustrated children's novels from the series TKCP and many more, many other picture books and activity books. She is the editor-in-chief of the new publishing house "Strange Forest".

The book-novel "Zvezda Mrak and the Creatures from Straskograd" (2019) by BiljanaCrvenkovska, published by "Strange Forest", brings to the Macedonian young readers an unusual reading, which on the one hand is in line with the latest interest and trend of dark adventure (fantasy) in literature for children and youth, on the other hand, because of the topics it brings, it can be freely said that it has its roots in folklore. The adventure that Crvenkovska begins introduces young readers to the sphere of horror, morbid and grotesque,but in a fun way. Identified as a bookworm (a book that is read from the back or upside down),in that story things are not as they seem. Thus the whole principle of reversal is present at thelevel of the whole story and deconstructs the stereotypes of the dichotomy black - white $=$ bad - good.

Of course, the book also expresses topics that are not treated so often and so openlyin our cultural environment. It is written and drawn in the spirit of the world trend for stories / and movies with ghosts, witches, monsters (but also in the spirit of the famous Adams / "TheAddams Family") as an extremely original, witty and inventive Macedonian teen book.

\footnotetext{
${ }^{1}$ Blesok, retrieved from website of the day 23.12.2020, http://blesok.mk/mk/authors/\%D0\%B1\%D0\%B8\%D0\%B\%D1\%98\%D0\% B0\%D0\%BD\%D0\%B0-\%D1\%86\%D1\%80\%D0\%B2\%D0\%B5\%D0\%BD\%D0\%BA\%D0\%BE\%D0\%B2\%D1\%81\%D0\%BA\%D0\%B0
} 


\section{Analysis of the work "Zvezda Mrak and the Creatures from Straskograd" by Biljana S.Crvenkovska}

As mentioned before, the book begins quite strangely - it is read on-the-reverse, moreprecisely from the end, and the reader moves in the direction of the beginning, as we define it. Even after flipping the book over the back page, for better coping, the author provided specific instructions for easier reading. Since at the very beginning we have titled this article as "anti-story", we are obliged to find its connection, closer or farther with the story.

The characteristics of the fairy tale as a genre are well known: geographical / spatial temporal indeterminacy, black and white character painting, universality of the theme, landscapes, metamorphoses, fairy-tale creatures, magical objects, etc., etc. In this bookfor children, authorapplied an innovative procedure in the Macedonian literature, that is, achieved a symbiosis of the fairy tale as a genre, with a touch of horror / fiction and thus created a new type of fairy tale. She "complicated" the situation even more by turning the perspective / dichotomy of good-evil / good-ugly. That is why, first, we will look at this book in terms of its proximity or distance from the story.

In the first chapter (conditionally speaking), the author introduces us to the city of Straskograd, and at the same time, the fairy-tale beginning is evident: "Once, recently, right now, and maybe tomorrow, in the near or distant future, there was, there is and there will be - one city.one city. It was called, it is called or it will be called - Straskograd" (Crvenkovska, 2019). With this debatable chronotope, the author diverts the reader's attention from the possible too serious understanding of the morbid scenes that follow, especially from the description of Straskograd: "It is located at the top of Sturid, and a narrow, narrow road leadsto it. There is a terrible abyss on the right side of the road. From those abysses that often fall into if the wrong step is taken"(Crvenkovska, 2019). Of course, such a city is characterizedby all the fairy-tale elements, such as the existence of a castle, but what: "The city is surrounded by strong stone walls, and in its center rises a huge ant castle (brrrr) called Crnokule. The castle, of course, has a high tower with a secret chamber on the roof, as wellas its own secret passage, oh yes! From those dark, narrow, wet tunnels that go out of town and through which you can escape in case of need. Dark, cobbled cobbled streets, full of dilapidated, gray houses and dubious shops with extremely strange and unknown objects are sold throughout the city." (Црвенковкка, 2019). This description of the city and its entire surroundings, inevitably imposes on us the impression of another work of Macedonian children's literature - "Sedmička malata vešterička" by Slavka Maneva. Here, as well as there, a gloomy description of the topos in which the action takes place is given, ie. a description of the place of residence of the characters, which is a typical topos of horror and fiction. This is reinforced by the fact of the existence of the country where this city with a frightening name is located, and that is Novostara Nepoznanija, about which no one knows where it is located.

For better management of the readers, the author offers a very picturesque map, fromwhich you can see all the strangeness of the fairy-tale landscape. There, on the one hand, Novostara Nepoznanija is surrounded by an ocean full of sharks and pirates, and on the otherhand by unknown lands in which no one has set foot, and waters in which "probably" there isa sea monster (which no one has seen yet)! There is also on the map and: "... two cities - Straskograd and Sretkovo, one village - Skrzovo, Eerie mountains, Mrakshuma, several smaller hills, rivers that flow upwards..." (Crvenkovska, 2019). Once the author has positioned the action, she turns to the people of that country, in particular, to the people of Strashkograd"In Strashkograd live just ugly, ugly, ugly, horrible, hated of all creatures! Exactly! Who? Eh, who! All those you are a little afraid of or disgusted with when you think of them. These are just some of them, and you add with others: spiders, snakes, frogs ... Plus in Straskograd livesome creatures that are considered SCARY, such as monsters and ghosts. Ооооо!" (Црвенковска, 2019). The very phrase "considered terrible" implies imposed beliefs, prejudices against others, as the author explains: "Yes, nasty and scary creatures are not nasty or scary. Someone loves them just like that. And someone else, who may not like themso much, knows that one should not judge by appearance. And that sometimes, the beautifulthings inside are rotten, and the ugly ones ... well, they can hide something unexpected, evenprecious. Well, this is a story about the oppressed, poor creatures that many people hate for no reason just because of their looks, because of some stupid prejudices and superstitions orsimply because they do not understand them!" (Crvenkovska, 2019) 
Indeed, not only this excerpt, but this whole, seemingly small booklet carries a great message. The main heroine of Straskograd is Zvezda Mrak, about which, like all the inhabitants of this monastic city, the author gives us detailed information, appearance, what he wants, what he does not want, etc. From the description we learn that Zvezda Mrak is an orphan girl, who lives in her own castle with her friends, has unusual favorite dishes and drinks: "Favorite drink: boiled frog saliva, with lemon and cinnamon. Favorite food: candy of cobwebsand toasted sugar" (Crvenkovska, 2019). It is no accident that this description is inserted andwhat the children do not want - toasted sugar candy. This is done in order for the children to recognize themselves in the character of the heroine and to identify with her. It is even strongerwhen the things she does, what she likes or does not like are emphasized, and that is: "Occupation: housing unwanted creatures... she does not want: injustices, bad people, spoiledprinces and princesses. Secret wish: to find a friend! Zvezda is very withdrawn, so finding friends is an impossible mission for her. Shmrc!" (Crvenkovska, 2019). From the above passage, several things are evident: first, the nobility of the Zvezda Mrak and its great heart for all rejected animals is obvious; second, she is down to earth and realistic she does not like artificial and pampered behavior, and third, she is - lonely, like any child. These are the characteristics of a child, from the present, past and future, on the path of his growth.

And growing up Star Trek, like every thirteen-year-old girl, is about writing a diary. Andthis is quite common, because our heroine read it in another book for adolescents: „First of all, I would like to tell you how it came about that you became my diary, my new best and mostfaithful friend - the one who will keep all my secrets. Well, like this ... I read a big, very interesting, scary, DARK book - "Miss Boo's Travels" and it said that a girl my age (thirteen oras Chupi says - thirteen) should write a diary" (Crvenkovska, 2019). Here the author appears as a great connoisseur of the life of adolescents, because she points out books that are closeto them, and through the example of the heroine she also points out how they can make their own diary: "I made you myself and I am very proud of that: sheets of paper, paints, cardboard,pieces of material and leather and of course - those few ingredients needed to revive paper, cardboard and other materials, and they are: WHISPER, SECRET, STAR and MOON. Wow -here you are! You are here! My best friend." Indeed, the Zvezda Mrak diary becomes the most faithful friend who first introduces him to her surroundings, to the fact that she is an orphan: "It means that I have no parents. Yes, that's right, it's very sad, and it's especially sad that I don't even remember my parents. I do not know what they looked like, nor where and why they disappeared ..." (Crvenkovska, 2019). The diary becomes a friend to whom she confides her joys and sorrows, her doubts. In fact, through her intimate conversation with thediary, we meet the other inhabitants of Straskograd: the monster Chupi (heroine guardian), the pet rats Tristan and Isolde, the raven Mortimer (heroine teacher), Globe, the ghost-keeperin the castle. She also describes the inhabitants of the town of Sretkovo to the diary (and to us, the readers!).

Earlier we mentioned the proximity of this work with the work "Weekly Little Witch" bySlavka Maneva. Here, as well as there, there is a parallel existence of two opposite worlds: the world of humans and the wizarding world. In Crvenkovska's work, we meet the two cities of Straskograd and Sretkovo, as well as the village of Skrzovo. We have already talked aboutthe inhabitants of Straskograd, and the inhabitants of Sretkovo are completely opposite to thepreviously mentioned: „I is a city where Princess Rosa lives with her "cute" animals. That is,everyone from Skrzovo thinks that they are cute, and that Rosa is a beautiful, miraculously good princess" (Crvenkovska, 2019). Zvezda Mrak reveals the reason for the existence of antagonism between her and Princess Rosa, between Straskograd and Sretkovo, and that is the existence of magic, which does not only affect the inhabitants of Straskograd: „.... they areso wrong, because Rosa is everything but good! I do not know how to explain to them that she is not good and that she in some insidious way enchants everyone to believe in it!" Princess Rosa uses this magic for her own dark purposes: "And then after you spellbound, she uses and it obliges to perform various unpleasant things, without question" (Crvenkovska, 2019).

In this way, the character of Princess Rosa does not even closely resemble the princesses from the fairy tales we know. First, she has a name - Rose, which is not unusual, but is in the context of what she does, enchants, and the text mentions that in Sretkovo rosesspread their intoxicating scent everywhere (rose-flower-scent!). Namely, with magic in Sretkovo, everyone who walks there to do what she does is enchanted. Thus, the name of theprincess is a condenser of the narrative program. The appearance 
of the town Sretkovo itselfis enchanting: "The city, like the palace, is bright, white, clean, rich... Large spacious streets, large multi-storey houses, bright green lawns, full of beautiful roses whose strong scent spreads throughout the city. Cute, cute white kittens and just as cute and gentle pink bunnies walk the streets.....Има и тиркизни морски прасиња, виолетови пудлици, рајски птици со шарени пердуви и раскошни пауни..." (подвлеченото -мое, J.Д.) Crvenkovska (, 2019).

The first part of the excerpt reveals Sretkovo as a completely normal, beautiful city that everyone would like to stay in, while in the second part, with the unusual colors of the animalsfound there (turquoise guinea pigs, purple poodles), the exaggeration indicates of a fairy-taleimpression, which is hard to believe and despite its splendor, which the Zvezda Mrak (in this chapter) calls "The false glow of Sretkovo". And the illusion that this city causes, despite all itssplendor, can only be discovered by special people who see the essence of things. Only Zvezda Mrak succeeded in that: "Only this little girl, who was only ten years old at the time, was not blinded by the false glow of the city and its inhabitants On the contrary, as soon as she entered the city (and she had come there at the invitation of Princess Rosa), Zvezda stoodstunned. And no, it was not because of the beauty of Sretkovo, as other travelers used to be petrified. No, Zvezda is startled by fear! Because the moment he saw the white kittens, the pink bunnies and the turquoise guinea pigs, Zvezda saw them exactly as they were - horrible,evil creatures! She saw their sharp teeth, looked into their evil eyes, and heard their caressing, vile voices. She heard Rosa's seemingly kind words, which in essence were completely false,and behind them was a desire for power and a need to rule over everything "(underlined-my,J.D.) (Crvenkovska, 2019).

The third topos that is revealed to us in this unusual book is the village of Skrzovo:"Near Straskograd is the village of Skrzovo, whose inhabitants, as the name suggests, are a bit stingy. They do not want to share things with each other, everyone sees only their own, which is the reason for the frequent quarrels between them " (Crvenkovska, 2019). As beforewith other topos / personal names, this topos reflects the nature of its inhabitants. The peoplefrom Skrzovo are shown as an amorphous mass, which is placed between Sretkovo and Straskograd and from such a dark place, emerges the best, only human friend of Zvezda Mrak - the boy: "My new friend's name is Nino. It took me a while to find out his name, because hecan not speak. In fact, Nino is dumb"; "He, the poor man, escaped from the children from Skrzovo, who insulted him and threw stones at him. Poor, poor Nino! I do not know how can someone be so evil? Didn't anyone teach those children that they should be good and kind and that only then will it come back to you nicely? " (Underlined by me- JD) (Crvenkovska,2019). This may be one of the key sentences - the leitmotif of this book, especially since it willlater be shown that he is a real hero on the side of good: " Nino is modest, but a very brave dumb boy from Skrzovo. Although he often serves as a mockery to those rude children from Skrzovo, Nino is always a good, gentle and faithful friend. He is also a very cheerful and cheerful boy, especially after he met Zvezda "(underlined by me, JD) (Crvenkovska, 2019). Nino will later prove to be a true friend, when he reveals to Zvezda Mrak that the villagers from his village Skrzovo succumbed to the intrigue organized by Princess Rosa that the creatures from Straskograd are harming their grain. Well, they occupy the castle with the desire to demolish it. The friendship of Zvezda and Nino withstands all temptations, and proves to be real when Nino disguises himself as the hero who will save Straskograd from the villagers of Skrzovo, or rather he will send them a letter written by Mortimer, in which he reveals their intrigue and its main organizer - Princess Rosa. Previously quoted escarps show the attitude of the people from Skrzovo, who are no one else, but all those people who with contempt, ridicule or rudeness, treat all those who are different from us, for the sole reason that they do not understand or they don't want to understand them. Simply put, along the line of least resistance or environmental impact, it is easiest to dismiss them as something that deviates from normal. Such is the case with Nino, who will be physically attacked: "Imagine, he did notcome because those evil children beat him and completely bruised one of his eyes, so he could not see with him. "He had to lie at home with ice in his eye, and his mother was very, very worried." Maybe that's why Nino's only wish was to "one day live in a place where all children are like him - different" (Crvenkovska, 2019).

Because of her unusual appearance, Zvezda Mrak is also ridiculed, discriminated, underestimated, rejected and stigmatized by her peers from Skrzovo, who called her: "Witch!Bad luck! See what you are like!" (Crvenkovska, 2019), they hit her hard deep inside, even though she ignores the insults. In fact, it's the way she learned to deal with the insults directedat her. However, from time to time it evokes melancholy 
moods: "Today is a sad day for me. From those days when I have a lump in my stomach that does not want to go away. And whentears come to me for no particular reason. That is, there is a reason, but it is nothing new ..." (Crvenkovska, 2019).

All the inhabitants living in Straskograd are: the spider Ariadne, the kitten Mufi, the monster Chupi, the raven Mortimer, the Globe-spirit guardian of the castle Crnokule, the rats Tristan and Isolde, the messenger bats Archimedes and Archibald, and at the end another miracle joins them, the pink Petunia, allegedly expelled from Sretkovo, and later turns out to be a "Trojan horse" in order to secretly open the gates of Straskograd and let the enemies in. Her plot is revealed thanks to the always curious spider Ariadne: „Ariadne is a spider, gossip and the main city spy in Straskograd. Nothing can go unnoticed by Ariadne, nor can anythingpass without Ariadne ... We must note that Ariadne has a very positive quality: when she learns a big, dangerous secret, she does not tell it to anyone, but immediately go to Chupi orZvezda" (Crvenkovska, 2019). There lives the raven, who is also a teacher of Zvezda, the oldest and wisest inhabitant, as opposed to the ingrained understanding among people (whichoriginates from folklore) that its appearance and sinister construction are associated with misfortune, death, bad news, etc. ... Like any castle with ghosts (Globe spirit), spiders and cobwebs, ravens, rats and black cats, the character of the monster Chupi should not be left out:, Chupi is a very old creature of the hairy scarecrow type, the ones that usually hide underchildren's beds. But it is wrong to think that hairy scarecrows crawl under cribs to stalk children, to frighten them or, God forbid, to eat them. Not at all. Hairy scarecrows have a desire to listento children's dreams, because they help them fall asleep easier, so from their sound they fall asleep peacefully under the bed" (Crvenkovska, 2019). And all these characters of creaturesof which only Zvezda and Nino are in human form, and even they are repulsive to the peopleof Skrzovo and Sretkograd due to some of their features, the author Crvenkovska did not choose them by chance. On the contrary, their presence introduces young readers to a greattruth - that they are not all the same, that one should be open-minded and hands-on about everything that is different from us...

In fact, if we look at all the inhabitants of Straskograd, we will easily see that all of them, in one way or another, have been rejected from their environment and condemned to ridicule, attacks, humiliation ... One of those inhabitants of Straskograd is also - Mufi. Muffy was a black Angora cat, whose only misfortune was that "he was born in Sretkovo, in a litter of pure white Angora kittens, and - as the only black kitten in the litter, he was declared a phallic! Mufi was thrown out of Rosa's guards outside Sretkovo ramparts, straight into Mrakshuma, and left at the mercy of wild beasts living there " (Crvenkovska, 2019). This reflects the superstition associated with the accident, allegedly carried by black cats.

Playing with the postulates on which the fairy tale is based, the dichotomy of good and evil deserves special attention. Speaking about good and evil as categories in children's literature, Natka Mickovič points out that if everything is left only to the black and white painting of the world in children's literature, i.e. if "moral instruction is the ultimate tendency of the work", it can "destroys the work and prevents it from existing as an aesthetic function". So, if he stays in that pattern, the work will lose sight of the nuances in our existing world, will ignore the motivations that people determine towards one or another type of behavior in all its diversity, will overlook all the diversity of our lives in which nothing is so simple, contrasted intwo colors". In this novel, Biljana Crvenkovska not only completely deviated from the schematic black and white painting of the characters, and even reversed the dichotomy of the two oppositely placed categories of good-evil, beautiful-ugly, placing them in two completely opposite categories. Deviating from the principle that is present in classic fairy tales, such as those of the Brothers Grimm, where the characters of deformed witches, elves, dragons and other characters with physical differences are portrayed as metaphors for the inner qualities of these characters, were associated with certain negative and even evil tendencies. But today this is inadmissible and it is expected in contemporary literature, characters with diseases or some disability, to be actively integrated into society, to feel and experience relationships with characters without disability / disease and to have the opportunity to act or have a choice. Therefore, the characterization of the characters in contemporary children's literature should be positive and realistic (Taylor, Prater 2005). Hence, it is quite justified for professionals to point out that it is very important for children to learn about diseases or disabilities through teaching curricula and over time when children will have the opportunity to communicate or be in the same grade / class with someone who is with illness / obstacle / deficiency, to havesome 
foreknowledge and understanding (Blaska 2004). Blaska, which even outlines ten criteria according to which writers who write on this subject should be guided, points out that in children's books with such characters, one should not claim the disease of the character asits main feature, but the emphasis should be placed on its force. Or, as Tina Taylor Dyches and Mary Anne Prater point out, these people should not be portrayed as objects of concern,but as someone who contributes to society. According to Smith-D'Arezzo, students in the school should be introduced to the characters of children with disabilities / diseases in which these children are seen as someone that readers would like to meet or be friends with. That is, these characters should be portrayed in a positive light, which does not mean that they should not be portrayed realistically, including all their flaws (Smith-D'Arezzo 2003). This is exactly how Biljana S. Crvenkovska portrays the characters in this novel. Namely, in this unusual novel, which is read upside down, everything is upside down from the classic storiesin which we are accustomed to goodness and beauty going hand in hand, princesses to be kind, quiet, beautiful, good, etc., and the bad, the evil, the evil, the unusual, the unknown, etc. it was almost exclusively associated with the ugly, the disgusting, the horrible, etc. The author seeks to break down stereotypes and prejudices about people who are different for some reason, not through their own fault, on the one hand, but also to encourage young readers, children, to try to get closer and get to know them. Zvezda Mrak also realizes that: "I thought a lot and realized what we all have in common here in Straskograd, and here I include Nino ...Do you know what we are the same? In that the people around us do not like us. And I think they do not like us because they do not understand us at all "..., And let me tell you somethingelse, how I actually connected things. I thought that, in the same way that the villagers do notlike Tristan and Isolde (the rats-pets of Zvezda Mrak-inserted mine, JD) and the spiders and the black cats ... so the children from Skrzovo do not like me and Nino..." (Crvenkovska, 2019). In her thinking lies the message of this small in size but grand in message novel. The inhabitants of Straskograd, each different from each other, both in appearance and behavior,and in speech, live in harmony in Straskograd, and each of them carries a good and friendly soul, faithful to the end of Zvezda Mrak:,Yes, to some people nasty and scary creatures are not nasty and scary. Someone loves them just like that. And someone else, who may not likethem so much, knows that one should not judge by appearance. And that sometimes, the beautiful things inside are rotten, and the ugly ones ... well, they can hide something unexpected, even precious. Well, this is a story about the oppressed, poor creatures that many people hate for no reason just because of their looks, because of some stupid prejudices andsuperstitions or simply because they do not understand them." (Crvenkovska, 2019).

Books are a kind of mirror for children in which they see characters who look like them, have the same feelings and experiences. Books also serve as windows through which childrenlearn about the world, looking through the windows through their current environment and getting to know the characters and events that are in their environment, but also around the world. (Blaska 2004). The limited presence of characters with disabilities in children's literature indicates the need for more stories that represent the differences in society, including peoplewith different abilities. While most textbooks for the disabled have been published recently, the percentage is still very small compared to the total number of children's books published annually. (Blaska 1996).

\section{Conclusion}

The book "Zvezda Mrak and the creatures from Straskograd" by Biljana S. Crvenkovska is the best example of how many things can be explained and approached to children and to open new horizons for them, to avoid the marginalization of certain children with special needs. Through a successful combination of story and horror (taken from fiction), but given in an inverted perspective, he builds a story about the city of Straskograd, which is only seemingly scary, and in fact "shines" from the inner beauty of its inhabitants, unlike Sretkovo, in which seemingly shines and smells pleasant, but its inhabitants have corrupt thoughts and souls. In that way, Crvenkovska turns this tale into an anti-tale, destroys the tale,to prove and show that things are not always as they seem. In Sretkovo everything is beautifulin appearance, but not in spirit, while in Straskograd, things are the opposite. Skrzovo, on the other hand, is a completely different story. The city of people exists between good and evil, and their actions give the impression that they are an amorphous, weak-minded mass that iseasily controlled. 
At one point, under the influence of Princess Rosa's intrigues, they set out on a campaign against Straskograd and lynched its inhabitants, only to be easily convinced of Rosa's malice. And, finally, Zvezda points out their volatile nature, when she says that she is aware that the goodness towards Straskograd will last for a short time, and they will soon fall under the magic of Rosa, ie. evil. With that, the author seems to say that evil never sleeps, it always lives here and between us, along with the good (as in a true story, but also as in life!), But the message is that we should never give up learning to look at things in their essence. Or, as Antoine de Saint-Exupery would say: "The essence is seen with the heart, not with the eyes."That is why, at the end of Crvenkovska's novel, another resident moves into Straskograd, rejected by the others: "This is Vilen, the mysterious boy with a metal hand whose front part can be turned into any tool: hammer, saw, magnet, ax! Yes, yes, imagine! Although he does not have one hand, Vilen from Straskograd becomes a skilled master ....

Vilen is an abandoned, poor child who wandered through the Strangers and managed as he knows how" (Crvenkovska, 2019).

The novel ends with the victory of good over evil. However, the author announces a new adventure to young readers, by announcing a new, more terrifying monster that is approaching Straskograd, but also by rounding up the doubt whether there are any unknowns, which captures the fantastic effect in the work. If we accept the term fantastic, in the narrower sense of its meaning, then there is very little fiction in children's literature. This is logical, given a number of reasons of a psychological and pedagogical nature. "The destructive and shocking nature of such fiction - devils, demons, vampires, werewolves, witches, curses with terrible vengeance and many other props of the evil imagination, regardless of their often complex meaning, can have a double effect on the child-reader." All that world, the child can accept a milder intensity, as usually happens with the marvelous world of the tale, but such acceptance means avoiding the primary objectives of that kind fiction. On the other hand, the child may experience a strong feeling of fear, insecurity and confusion, with traumatic consequences for the psyche" (Vukovič, 1979: 12).

Furthermore, Novo Vukovič opposes the character of the fiction of the child psyche: "Most of the modern fiction, which in the opinion of many theorists of that genre exists in the neighborhood of psychiatry and psychoanalysis, turns out to be too" heavy food" for children. Renouncing mainly the imagination of evil, the fantastic in children's literature hardly realizes that special intensity, shock, scandal of reason and specific panic that as a rule realizes in children's literature. These effects are difficult to cause, not only because of the lack of destructiveness in the imagination, but also because of the nature of the "consumers" of children's literature" (Vukovič, 1979: 13).

\section{References}

Blaska, Joan. K. (1996). Using Children's Literature to Learn About Disabilities and IIIness, Practical Press; First Edition.

Blaska, Joan. K. (2004). Children's Literature That Includes Characters with Disabilities or IIInesses, Disability Studies Quarterly Winter 2004, Volume 24, No. 1, Retrieved from: www.dsq-sds.org,

Mickovič, N., (1985). Deteto i literaturata za deca, [The child and children's literature]. Skopje: Makedonska kniga.

Micković, N., (1988). Literaturata za deca i nejzinite vospitni možnosti, [Children's literature and its educational possibilities] Skopje: Samoupravna praktika,

Vukovič, N., (1979) Iza granica mogučeg, Beograd: Naučna knjiga [Beyond the limits of the possible] Belgrade: Scientific book

Smith-D'Arezzo, Wendy M. (2003). Diversity in Children's Literature: Not Just a Black and White Issue, Children's Literature in Education, Volume 34, Issue 1, pp 75- 94, https://doi. org/10.1023/a:1022511917336 https://link.springer.com/article/10.1023/A:1022511917336

Taylor Dyches, Tina., Prater, Mary Anne, (2005). Characterization of Developmental Disability in Children's Fiction, Education and Training in Developmental Disabilities, 40(3), 202-216. https://www.jstor.org/ stable/23879716?seq $=1$

Crvenkovska, B., (2019) Zvezda Mrak I suštestvata od Straškograd Skopje: Čudna Šuma [Star Dark and the creatures from Straskograd], Skopje: Strange forest 